\title{
Electro-oxidation of Amoxicillin using Titanium Electrodes \\ Electrophoretically Coated by Iridium or Ruthenium with \\ Tantalum Oxides
}

\author{
I. León, ${ }^{\text {a H}}$ H. I. Gomes, ${ }^{b}$ S. Sepúlveda-Guzmán, ${ }^{\mathrm{c}}$ J. Cárdenas, ${ }^{\mathrm{a}}$ \\ F. F. Rivera, ${ }^{a}$ J. Manríquez ${ }^{\mathrm{a}}$ and E. Bustos ${ }^{\mathrm{a}, *}$
}

a Centro de Investigación y Desarrollo Tecnológico en Electroquímica, S.C.,

CIDETEQ, Parque Tecnológico Querétaro, Sanfandila, Pedro Escobedo, 76703,

Querétaro, México.

${ }^{b}$ Food, Water, Waste Research Group, Faculty of Engineering, University of Nottingham, University Park, Nottingham, NG7 2RD, United Kingdom.

c Facultad de Ingeniería Mecánica y Eléctrica, FIME, Universidad Autónoma de Nuevo León, UANL, Ave. Pedro de Alba s/n, Ciudad Universitaria, 66455, San Nicolás de los Garza, Nuevo León, México.

\section{Paper submitted to be published in Journal of Chemical Technology and Biotechnology}

*Corresponding author: Tel.: +5244221160 59; fax: +52 4422116001. E-mail address: ebustos@cideteq.mx (E. Bustos) 


\section{ABSTRACT}

BACKGROUND: Amoxicillin (AMX) has been one of the pharmaceutical compounds in waters targeted in wastewater decontamination studies, some of the technological alternative to degrade them is using modified surfaces with transition metal oxides, such as $\left|\mathrm{rO}_{2} / \mathrm{Ta}_{2} \mathrm{O}_{5}\right| \mathrm{Ti}$ and $\mathrm{RuO}_{2} / \mathrm{Ta}_{2} \mathrm{O}_{5} \mid \mathrm{Ti}$, for in situ production of hydroxyl radical $\left({ }^{\circ} \mathrm{OH}\right)$ to oxidize $\mathrm{AMX}$ in aqueous media.

RESULTS: The $\mathrm{IrO}_{2} / \mathrm{Ta}_{2} \mathrm{O}_{5} \mid \mathrm{Ti}$ 70:30 electrode was best suited for AMX electrooxidation, with $99.23 \%$ removal measured by HPLC-UV-Vis, $81.13 \%$ by COD removal and current efficiency of $41.1 \%$ in $0.1 \mathrm{M} \mathrm{Na}_{2} \mathrm{SO}_{4}$ after applying $15 \mathrm{~mA}$ for $6 \mathrm{~h}$. These results are due to a larger surface area $\left(251.67 \mathrm{~cm}^{2}\right)$ and a higher amount of ${ }^{\circ} \mathrm{OH}$ radicals generated by $\mathrm{cm}^{2}$ in neutral $\mathrm{pH}\left(3.8 \mathrm{M} \mathrm{cm}^{-2}\right)$ compared to the other electrodes.

CONCLUSION: This paper shows the simulation of the experimental data regarding the complete degradation of $\mathrm{AMX}(100 \%)$ by HPLC comparing the experimental results and simulation results for $A M X$ degradation using the $\left|\mathrm{rO}_{2} / \mathrm{Ta}_{2} \mathrm{O}_{5}\right| \mathrm{Ti} 70: 30$. The modeling predicts and validates the disengagement of COD obtained experimentally considering the mechanism proposed by Trovó and collaborators for the electro-oxidation of $\mathrm{AMX}$ to product $\mathrm{C} 6\left(\mathrm{C}_{16} \mathrm{H}_{22} \mathrm{~N}_{3} \mathrm{O}_{7} \mathrm{~S}\right)$ by generating ${ }^{\circ} \mathrm{OH}$. 
KEYWORDS: Antimicrobial resistance, transition metal oxides, modified surfaces, electrochemical advanced oxidation processes. 


\section{INTRODUCTION}

Antibiotics are among the most commonly detected pharmaceutical products in aquatic environments; as they are not removed in wastewater treatment plants. ${ }^{1-2}$ The presence and fate of antibiotics and their degradation products in water bodies is recognized as one of the emerging environmental and public health problems, as they can cause antibiotic resistance. ${ }^{3}$

Several treatment methods have been developed to remove antibiotics from wastewater. Electrochemical advanced oxidation processes (EAOP) are based on in situ production of the highly reactive hydroxyl radical ( $\left.{ }^{\circ} \mathrm{OH}\right)$, a powerful oxidizing agent to remove organic contaminants. ${ }^{4}$ In this context, EAOP are simple, cost-effective, safe, and environmentally compatible technologies for water treatment. ${ }^{5-7}$ These technologies are currently focused on improving the conversion efficiency of pollutants, including materials used as anode, which plays a role in the generation of oxidizing species for the transformation or degradation of pollutants in solution. ${ }^{8}$ These anodes can be modified with transition metals with different compositions, which favor the generation of oxidizing species such as ${ }^{\circ} \mathrm{OH},{ }^{\circ} \mathrm{OOH}, \mathrm{H}_{2} \mathrm{O}_{2}$, and $\mathrm{O}_{3}$ to carry out EAOP. ${ }^{9-11}$ Some electrodes used in EAOP are made with transition metal oxides as $1 \mathrm{rO}_{2} / \mathrm{Ta}_{2} \mathrm{O}_{5} \mid \mathrm{Ti}$ and $\mathrm{RuO}_{2} / \mathrm{Ta}_{2} \mathrm{O}_{5} \mid \mathrm{Ti}$, which have been used in the electrokinetic treatment of soils and water polluted by organic compounds ${ }^{12-14}$ due to their high generation of hydroxyl radicals, electrochemical and morphological characteristics, mechanical resistance under severe conditions of anodic attack, ${ }^{15}$ low potential and corrosion 
resistance. ${ }^{15}$ Different techniques have been used for modification, such as immersion, painting, and electrophoretic deposition. ${ }^{14}$

The study of the thermodynamics and kinetics of oxidizing agents generated by transition metal oxides such as $\left|\mathrm{rO}_{2} / \mathrm{Ta}_{2} \mathrm{O}_{5}\right| \mathrm{Ti}$ and $\mathrm{RuO}_{2} / \mathrm{Ta}_{2} \mathrm{O}_{5} \mid \mathrm{Ti}$ is essential to understand better the processes involved and thus advance their application. Electrochemical impedance spectroscopy (EIS) is a useful tool, as it allows measuring the response of an electrochemical system. As EIS depends on the frequency, it can reveal the underlying electrochemical processes in the system. Previously, the general reported mechanism suggested for $\mathrm{O}_{2}$ evolution in transition metals oxide-modified surfaces $\left(\mathrm{IrO}_{2}\right.$ and $\left.\mathrm{RuO}_{2}\right)$ was the following, ${ }^{16}$ considering the general reaction 1 , as well as reaction products such as hydrogen $\left(\mathrm{H}_{2}\right)$ and oxygen $\left(\mathrm{O}_{2}\right)$, generated at the cathode (reaction 2) and anode (reaction 3), respectively, under acidic conditions:

$$
\begin{array}{lr}
\mathrm{H}_{2} \mathrm{O} \rightarrow \frac{1}{2} \mathrm{O}_{2}+\mathrm{H}_{2} & \text { Reaction 1 } \\
2 \mathrm{H}^{+}+2 \mathrm{e}^{-} \rightarrow \mathrm{H}^{\bullet}+\mathrm{H}^{+}+\mathrm{e}^{-} \rightarrow \mathrm{H}_{2} & \text { Reaction 2 } \\
2 \mathrm{H}_{2} \mathrm{O} \rightarrow \mathrm{HO}^{\bullet}+\mathrm{H}_{2} \mathrm{O}+\mathrm{H}^{+}+\mathrm{e}^{-} \rightarrow \mathrm{O}^{\bullet}+\mathrm{H}_{2} \mathrm{O}+2 \mathrm{H}^{+}+2 \mathrm{e}^{-} & \\
\rightarrow \mathrm{HOO}^{\bullet}+3 \mathrm{H}^{+}+3 \mathrm{e}^{-} \rightarrow \mathrm{O}_{2}+4 \mathrm{H}^{+}+4 \mathrm{e}^{-} & \text {Reaction 3 }
\end{array}
$$

In this mechanism, the active surface sites are represented with a $(\bullet)$, which can be a link between two tetra-coordinated metal ions or an unsaturated coordinated site. Additionally, only electrochemical reactions are considered, as 
they depend directly on the applied potential, species diffusion and other surface reactions. In addition, $\mathrm{O}_{2}$ is considered to be formed by an associative mechanism in the anode through intermediate $\mathrm{HOO}^{*}$ on the surface. ${ }^{16}$ Accordingly, the function of $\mathrm{Ta}_{2} \mathrm{O}_{5}$ is important because it is a sink for the generated protons $\left(\mathrm{H}^{+}\right)$, so to maintain the balance, $\mathrm{IrO}_{2}$ must be homogeneously distributed on the modified surface, which prevents it from facilitating oxygen evolution. ${ }^{17}$

$\mathrm{IrO}_{2}$ and $\mathrm{RuO}_{2}$ are two electrocatalytic materials capable of generating oxygen evolution via dissociative electro-adsorption of $\mathrm{H}_{2} \mathrm{O}$ in the form of $\mathrm{H}^{+}$ions (released into the electrolytic medium) and ${ }^{\circ} \mathrm{OH}$ radicals that remain chemisorbed on electrode surfaces. ${ }^{16}$ Further, $\mathrm{Ta}_{2} \mathrm{O}_{5}$ regulates $\mathrm{H}^{+}$transport during oxygen evolution electrocatalysis over $\mathrm{IO}_{2} / \mathrm{Ta}_{2} \mathrm{O}_{5}$ or $\mathrm{RuO}_{2} / \mathrm{Ta}_{2} \mathrm{O}_{5}$ mixtures. ${ }^{18}$

This generation of oxidizing agents at the interface level has attracted growing interest in the treatment of wastewater contaminated with persistent organic compounds. ${ }^{5}$ Some studies have evaluated the effect of the initial pharmaceutical concentration on the process efficiency for anodic oxidation, anodic oxidation with $\mathrm{H}_{2} \mathrm{O}_{2}$ production, electro-Fenton, photo-electro-Fenton UV, photo-electro-Fenton UV-solar processes, among others. ${ }^{19-20}$

Amoxicillin (AMX) has been one of the pharmaceutical compounds in waters targeted in wastewater decontamination studies. ${ }^{21}$ This drug has characteristics making it suitable for use as a model contaminant; it is a broadspectrum veterinary and human medicine, and it is one of the antibiotics most 
frequently found in waters. ${ }^{21} \mathrm{AMX}$ is a semisynthetic lactam antibiotic with a molecular formula of $\mathrm{C}_{16} \mathrm{H}_{19} \mathrm{~N}_{3} \mathrm{O}_{5} \mathrm{~S}-3 \mathrm{H}_{2} \mathrm{O}$ and a molecular weight of $419.46 \mathrm{~g} \mathrm{~mol}^{-}$ ${ }^{1}{ }^{21}$ Recent studies have shown that $A M X$ degradation has been carried out through different types of treatments, such as physical (e.g., adsorption) ${ }^{18}$ and biological (using seaweed) ${ }^{22}$ processes, as well as AOPs such as photo-Fenton treatment), ${ }^{23}$ anodic oxidation using $\mathrm{Ti} / \mathrm{Pt} / \mathrm{SnO}_{2}-\mathrm{Sb}_{2} \mathrm{O}_{4}$ and electro-Fenton treatment with a BDD anode. ${ }^{24-25}$ The use of anodic oxidation with high anodic potentials was achieved for AMX using different salts as supporting electrolyte, e.g., sodium chloride $(\mathrm{NaCl})$ and sodium sulfate $\left(\mathrm{Na}_{2} \mathrm{SO}_{4}\right)$.

The main objective of this study was to develop modified surfaces with transition metal oxides, such as $\left|\mathrm{rO}_{2} / \mathrm{Ta}_{2} \mathrm{O}_{5}\right| \mathrm{Ti}$ and $\mathrm{RuO}_{2} / \mathrm{Ta}_{2} \mathrm{O}_{5} \mid \mathrm{Ti}$, for in situ production of hydroxyl radical $\left({ }^{\circ} \mathrm{OH}\right)$ to oxidize $\mathrm{AMX}$ in aqueous media. A secondary objective was to model the HPLC and COD results considering the mechanism proposed by Trovó and collaborators ${ }^{23}$ for the electro-oxidation of AMX to the product $\mathrm{C} 6\left(\mathrm{C}_{16} \mathrm{H}_{22} \mathrm{~N}_{3} \mathrm{O}_{7} \mathrm{~S}\right)$ by generating ${ }^{\circ} \mathrm{OH}$.

\section{EXPERIMENTAL SECTION}

\subsection{Electrode preparation}

The surfaces of titanium cylinders $0.7 \mathrm{~cm}$ in diameter and $6 \mathrm{~cm}$ in height were modified. The arrangement used in the AMX oxidation process involved the titanium cylinder modified with $\mathrm{IrO}_{2}$ or $\mathrm{RuO}_{2} / \mathrm{Ta}_{2} \mathrm{O}_{5}$ as an anode, with a titanium 
mesh cathode around it (Figure 1). The titanium cylinders were modified in two steps: first, they were sandblasted and then etched with a $40 \%$ oxalic acid solution for 20 min. Finally, they were rinsed with deionized water and dried. Different precursor solutions were prepared by dissolving $\mathrm{H}_{2} \mathrm{IrCl}_{6}$ and $\mathrm{RuCl}_{3}$. $\mathrm{xH}_{2} \mathrm{O}$ (Strem Chemicals, $99.9 \%$ ) in $\mathrm{HCl}$ and $\mathrm{TaCl}_{5}$ (Strem Chemicals, $99.9 \%$ ) in isopropanol under vigorous stirring. The Ir:Ta ratios employed in the precursor solutions were 70:30 and 30:70. All electrodes were obtained by electrodeposition at a constant current density of $20 \mathrm{~mA} \mathrm{~cm}^{-2}$ for $20 \mathrm{~min}$, applying a constant stirring rate. After electrophoretic deposition, the formation of metal oxides was promoted by a two-step thermal decomposition: first, $523 \mathrm{~K}$ for 10 $\min$, and then, $723 \mathrm{~K}$ for $1 \mathrm{~h} .^{12,14}$

\subsection{Determination of oxidant agents}

Indirect detection of surface-generated ${ }^{\circ} \mathrm{OH}$ radicals was performed by UV-Vis spectrophotometry using a PerkinElmer Lambda XLS equipment, where the reaction of 1 mole of coumarin with 1 mole of ${ }^{\circ} \mathrm{OH}$ radical produces 1 mole of 7-hydroxycoumarin in $0.5 \mathrm{M} \mathrm{H}_{2} \mathrm{SO}_{4}$ and measured at a wavelength of $277 \mathrm{~nm}$ as reported in the literature. ${ }^{12,14}$ To assess the behavior of the modified surfaces in terms of ${ }^{\circ} \mathrm{OH}$ generation at neutral $\mathrm{pH}$, the same procedure was followed, but using $0.1 \mathrm{M} \mathrm{Na}_{2} \mathrm{SO}_{4}$ as a supporting electrolyte. 
QuanTOFIX Peroxide $25^{\circledR}$ test strips were used for hydrogen peroxide detection in solution using $0.5 \mathrm{M} \mathrm{H}_{2} \mathrm{SO}_{4}$ as a supporting electrolyte, applying a constant electrical current of $30 \mathrm{~mA}$ for 15 min under constant agitation in a 10 $\mathrm{cm}^{3}$ electrochemical cell with a two-electrode arrangement using modified surfaces as the anode and bare titanium mesh as the cathode (Figure 1). The strips were submerged in the cell and later compared to the color scale. The measurement range was $0,0.5,2,5,10$ and $25 \mathrm{mg} \mathrm{L}^{-1} \mathrm{H}_{2} \mathrm{O}_{2}$, with the color turning from white to increasingly blue.

To determine the superficial surface area of the different modified electrodes used in this research, cyclic voltammetry was performed. For this purpose, $\left|\mathrm{IO}_{2} / \mathrm{Ta}_{2} \mathrm{O}_{5}\right| \mathrm{Ti}$ or $\mathrm{RuO}_{2} / \mathrm{Ta}_{2} \mathrm{O}_{5} \mid \mathrm{Ti}$ was used as the working electrode. The experiments were performed in a $10 \mathrm{~mL}$ glass cell with $0.5 \mathrm{M} \mathrm{H}_{2} \mathrm{SO}_{4}$ (JT Baker, 98\%) as an electrolyte, at $298 \mathrm{~K}$. Pt wire (BASi) and $\mathrm{Ag} \mid \mathrm{AgCl} 3 \mathrm{M} \mathrm{NaCl}$ (BASi) were used as the counter-electrode and reference electrode, respectively. The tests were performed on a BASi-Epsilon ${ }^{\circledR}$ potentiostat from Bioanalytical Systems Inc. Prior to measurements, oxygen was displaced from the solution by bubbling ultra-pure nitrogen (Praxair, grade 5.0) for 10 min, maintaining a nitrogen atmosphere over the solution during the experiments. To obtain the surface area and roughness factor $(R)$ of the modified electrode, the capacitive current of the generated double layer was calculated as reported in the literature. ${ }^{26}$

\subsection{Determination of accelerated lifetime}


The accelerated lifetime of titanium surfaces modified with transition metals was evaluated using the methodology from the NACE TM0108-2012 standard. ${ }^{27}$ This standard is applicable to anodes composed of a titanium substrate with a catalytic coating of mixed metal oxide. This test method speeds up the failure time by operating the anode to a higher current than the application design requirements. The test was carried out with a galvanostatic arrangement, using the modified surface as an anode, bare $\mathrm{Ti}$ as the cathode and $1 \mathrm{M} \mathrm{H}_{2} \mathrm{SO}_{4}$ as the supporting electrolyte, applying $50 \mathrm{~mA}$, and performing chronopotentiometry on a BASi-Epsilon ${ }^{\circledR}$ potentiostat (Bioanalytical Systems Inc.) with agitation at 300 rpm, with a variation of $1.5 \mathrm{~V}$ as the end of the experiment, as defined by the standard.

\subsection{Electrochemical degradation of $A M X$}

Hydrodynamic curves were made to differentiate the kinetic, mixed and diffusion-controlled areas using $0.5 \mathrm{M} \mathrm{H}_{2} \mathrm{SO}_{4}$ as the supporting electrolyte and $0.1 \mathrm{mM}$ AMX as analyte. In these experiments, a two-electrode cell arrangement was used, using bare Ti mesh as the cathode and titanium surfaces modified with transition metal oxides as the anode (cylinders $0.7 \mathrm{~cm}$ in diameter and $6 \mathrm{~cm}$ of height, Figure 1). The volume of the cell used was $80 \mathrm{~mL}$, and the measurements were made under constant agitation at $300 \mathrm{rpm}$ using a new solution in each of the tests. The experiments were performed in duplicate, and the measure was started from the equilibrium potential at a rate of $50 \mathrm{mV} \mathrm{s}^{-1}$. These curves were 
made to observe the limit current of the process, i.e., the point at which the process is controlled by mass transport and remains constant. In this way, the working current for the degradation of AMX in aqueous medium was defined.

AMX degradation was carried out in an electrochemical cell with a twoelectrode arrangement, initially comparing three supporting electrolytes: $0.5 \mathrm{M}$ $\mathrm{H}_{2} \mathrm{SO}_{4}, 0.1 \mathrm{M} \mathrm{NaCl}$, and $0.1 \mathrm{M} \mathrm{Na}_{2} \mathrm{SO}_{4}$ (Fisher Scientific). After evaluating the results obtained and considering the literature, we decided to use $0.1 \mathrm{M} \mathrm{Na}_{2} \mathrm{SO}_{4}$ as a supporting electrolyte for all tests. ${ }^{21}$ For these experiments, electrolysis was performed in an electrochemical cell with $80 \mathrm{~mL}$ of supporting electrolyte $(0.1 \mathrm{M}$ $\mathrm{Na}_{2} \mathrm{SO}_{4}$ ) and $0.1 \mathrm{mM} \mathrm{AMX} \mathrm{(Across} \mathrm{Organics),} \mathrm{with} \mathrm{the} \mathrm{titanium} \mathrm{surfaces} \mathrm{modified}$ by transition metal oxides as the anode and a cathode of titanium mesh. Electrolysis was performed using an Aim \& Thurlby Thandar Instruments power source, applying $15 \mathrm{~mA}$ under a constant agitation of $300 \mathrm{rpm}$. To measure AMX degradation, $0.5 \mathrm{~mL}$ samples were removed every 20 min over $400 \mathrm{~min}$ of electrolysis starting at $40 \mathrm{~min}$; these samples were stored at $277.15 \mathrm{~K}$ for further analysis.

AMX concentration (and subsequent degradation) was measured by highperformance liquid chromatography (HPLC) with an ultraviolet - visible (UV-Vis) detector (1260 Infinity Series, Agilent Technologies). The mobile phase used was a buffer mixture of phosphates $\left(0.01 \mathrm{~mol} \mathrm{~L}^{-1}\right)$, with a $\mathrm{pH}$ of 4.8 , and acetonitrile $(A C N)$ at a ratio of $95: 5 \mathrm{v} / \mathrm{v}$, pumped at a flow rate of $1.3 \mathrm{~mL} \mathrm{~min}{ }^{-1}$ through a Sunfire ${ }^{\circledR} 10 \mathrm{~m} \mathrm{C18}(250 \times 4.6 \mathrm{~mm})$ at $300.15 \mathrm{~K} .{ }^{27-28}$ The UV absorption 
peaks at $229 \mathrm{~nm}$ were monitored to obtain the calibration curve, with the equation $A($ a.u. $)=4.8044\left(A M X \mathrm{mg} \mathrm{L}^{-1}\right)+0.3795$ and $\mathrm{R}^{2}=0.997$, considering a retention time of $5 \pm 0.8 \mathrm{~min}$. Data were recorded by LC1260 Infinity software. To calculate the AMX concentration, calibration curves were first established using $0,0.5,1$, $5,10,25,50$ and $100 \mathrm{mg} \mathrm{L}^{-1} \mathrm{AMX}$, allowing the concentration of samples during the electrolysis process to be calculated to determine the degradation of AMX.

AMX degradation was also monitored by chemical oxygen demand (COD) analysis according to Method 8000 using the Reactor Digestion Method defined in the Hach Water Analysis Manual ${ }^{28}{ }^{28}$ COD analyses were done in triplicate, with samples extracted during electrolysis to determine AMX degradation by the EAOP, measuring the values at $0,100,200,300$ and 400 min of electrolysis to evaluate the removal efficiency of COD using titanium surfaces modified with transition metal oxides, as well as naked Ti.

The specific energy consumption (EC, $\mathrm{kWh} \mathrm{m}^{-3}$ ) during electrochemical treatment was calculated according the equation $1,{ }^{29}$ where $E_{c e l l}$ is the average potential difference between the anode and cathode during electrolysis $(\mathrm{V}), \mathrm{I}$ is the current $(A)$ and $t$ is the electrolysis time:

$E C=\left(E_{\text {cell }} \mathrm{It}\right) /(1000 \mathrm{~V})$ Equation 1

The specific energy consumption per unit of mass of COD $\left(E_{s p}=k W h \mathrm{Kg}\right.$ $\mathrm{COD}^{-1}$ ) was calculated from equation $2,{ }^{30}$ where $\mathrm{V}$ represents the voltage, $\mathrm{I}$ is the 
electric current (in A), $t$ is the electrolysis time, CODt $=0$ min and CODt $=400 \mathrm{~min}$ represent the COD at the start to end of the electrochemical degradation process ( $\mathrm{mg} \mathrm{L}^{-1}$ ), respectively, and $\mathrm{V}_{\mathrm{s}}$ is the volumetric volume of the sample:

$E_{s p}=(1000 \mathrm{VIt}) /\left(D_{\mathrm{O}} \mathrm{t}=0 \mathrm{~min}-\mathrm{DQO}_{\mathrm{t}=400 \mathrm{~min}}\right) \mathrm{V}_{\mathrm{s}}$

Equation 2

To assess the effectiveness and feasibility of AMX degradation, the efficiency of the electrochemical current was determined from the decrease in the COD, where the reaction was operated in batch mode with a constant current. The COD data were used to calculate instant current efficiency (ICE, \%) using equation 3 as follows: ${ }^{30}$

$\operatorname{ICE}(\%)=\frac{\mathrm{FV}_{\mathrm{S}}(\Delta \mathrm{COD})}{8000 \mathrm{I} \Delta \mathrm{t}}$ Equation 3

where $\mathrm{F}$ is the Faraday constant $\left(96,485 \mathrm{C} \mathrm{mol}^{-1}\right), \mathrm{V}_{\mathrm{s}}$ is the volume of the solution (L), $\triangle \mathrm{COD}$ is the experimental COD decrease $\left(\mathrm{mg} \mathrm{L}^{-1}\right)$ in the time interval $\mathrm{t}(\mathrm{s})$, and $I$ is the current $(A)$.

To model AMX degradation was considered the mechanism reported by Trovó and collaborators. ${ }^{23}$ This model was applied in this study due to their practicality, as they did not involve too many kinetic parameters and considered 
ideal conditions in the system. The established reactions of this mechanism are presented as follows for amoxicillin $\left(\mathrm{C}_{16} \mathrm{H}_{19} \mathrm{~N}_{3} \mathrm{O}_{5} \mathrm{~S}\right)$ :

$$
\begin{array}{ll}
2 \mathrm{C}_{16} \mathrm{H}_{19} \mathrm{~N}_{3} \mathrm{O}_{5} \mathrm{~S}+11 \bullet \mathrm{OH} \stackrel{\mathrm{k}_{1}}{\rightarrow} 3 \mathrm{C}_{6} \mathrm{H}_{10} \mathrm{NO}_{3} \mathrm{~S} & \text { Reaction } 4 \\
\mathrm{C}_{16} \mathrm{H}_{19} \mathrm{~N}_{3} \mathrm{O}_{5} \mathrm{~S}+\bullet \mathrm{OH} \stackrel{\mathrm{k}_{2}}{\rightarrow} \mathrm{C}_{16} \mathrm{H}_{22} \mathrm{~N}_{3} \mathrm{O}_{6} \mathrm{~S} & \text { Reaction } 5 \\
\mathrm{C}_{16} \mathrm{H}_{19} \mathrm{~N}_{3} \mathrm{O}_{5} \mathrm{~S}+\bullet \mathrm{OH} \stackrel{\mathrm{k}_{3}}{\rightarrow} \mathrm{C}_{16} \mathrm{H}_{20} \mathrm{~N}_{3} \mathrm{O}_{5} \mathrm{~S} & \text { Reaction 6 } \\
\mathrm{C}_{16} \mathrm{H}_{22} \mathrm{~N}_{3} \mathrm{O}_{6} \mathrm{~S}+\bullet \mathrm{OH} \stackrel{\mathrm{k}_{4}}{\rightarrow} \mathrm{C}_{16} \mathrm{H}_{22} \mathrm{~N}_{3} \mathrm{O}_{7} \mathrm{~S} & \text { Reaction 7 } \\
\mathrm{C}_{16} \mathrm{H}_{22} \mathrm{~N}_{3} \mathrm{O}_{6} \mathrm{~S}+\bullet \mathrm{OH} \stackrel{\mathrm{k}_{5}}{\rightarrow} \mathrm{C}_{15} \mathrm{H}_{22} \mathrm{~N}_{3} \mathrm{O}_{4} \mathrm{~S} & \text { Reaction 8 } \\
\mathrm{C}_{15} \mathrm{H}_{22} \mathrm{~N}_{3} \mathrm{O}_{4} \mathrm{~S}+2 \bullet \mathrm{OH} \stackrel{\mathrm{k}_{6}}{\rightarrow} \mathrm{C}_{14} \mathrm{H}_{20} \mathrm{~N}_{3} \mathrm{O}_{3} \mathrm{~S} & \text { Reaction 9 }
\end{array}
$$

Then the velocity equations (equations 4 and 5) were solved for each of the above reactions using FlexPDE Professional Version 7.13/W64 3D software.

$$
\begin{array}{ll}
\frac{\mathrm{d} c_{\mathrm{i}}}{\mathrm{dt}}=-\mathrm{r}_{\mathrm{i}} & \text { Equation } 4 \\
\mathrm{r}_{\mathrm{i}}=\mathrm{k}_{\mathrm{i}} \mathrm{C}_{\mathrm{i}} & \text { Equation } 5
\end{array}
$$

To calculate $\mathrm{k}_{\mathrm{i}}$ (equation 6 ), the parameter $\mathrm{D}_{\mathrm{a}}$ was used, which adds physical meaning to the model, whose value was the quotient of the heterogeneous reaction constant, and the mass coefficient (Da) was calculated according to equation 7 , where $\theta$ is the coverage and $\mathrm{K}_{\mathrm{m}}$ is the mass transference coefficient: 
$\mathrm{k}_{\mathrm{i}}=\mathrm{k}_{\mathrm{i}}^{0} \theta\left(\frac{1}{1+\mathrm{D̈a}}\right)$

Equation 6

$\ddot{D a}=\frac{k_{i}^{0}}{k_{m}}$

Equation 7

\section{RESULTS AND DISCUSSION}

\subsection{Determination of oxidant agents using the modified electrodes}

Electrochemical characterization began with the determination of the surface area obtained by capacitance (surface areas Areal, Table 1). The geometric area (Ageo) was calculated from the cylinder measurements (same for all modified surfaces), and the roughness factor (R) was the quotient of both. The calculated surface area of the naked Ti was $95 \mathrm{~cm}^{2}$, with a roughness factor of 7 due to the sandblasting treatment of the surface. The largest calculated surface area and roughness factor were observed for the Ir-Ta 70:30 surfaces, with values of $251.67 \mathrm{~cm}^{2}$ and 18.5, respectively. The surface area of the Ru-Ta 70:30 sample as $153.33 \mathrm{~cm}^{2}$, with a roughness factor of 11.3 , followed by the surface areas of the Ru-Ta 30:70 and Ir-Ta 30:70 samples, with 128.67 and $126.67 \mathrm{~cm}^{2}$, respectively, which had roughness factors of 9.5 and 9.3.

Additionally, to quantify the $\cdot \mathrm{OH}$ radical concentration, a coumarin calibration curve was performed from 0.05 to $0.12 \mathrm{mM}$ coumarin by UV-Vis 
spectroscopy at $277 \mathrm{~nm}$. Electrolysis was performed with a concentration of 0.12 $\mathrm{mM}$ coumarin in $0.5 \mathrm{M} \mathrm{H}_{2} \mathrm{SO}_{4}$ (Figure $2 \mathrm{~A}$ ) and $0.1 \mathrm{M} \mathrm{Na}_{2} \mathrm{SO}_{4}$ (Figure 2B) as electrolytes to assess the surface's behavior at neutral and acid $\mathrm{pH}$. In these experiments, a $30 \mathrm{~mA}$ constant electric current was applied under constant stirring at $300 \mathrm{rpm}$ for $5 \mathrm{~min}$. The results showed that the production of ${ }^{\circ} \mathrm{OH}$ radicals increased at an acid $\mathrm{pH}$ due to the higher amount of protons available. In general, the surfaces showed a greater number of radicals generated in $0.1 \mathrm{M}$ $\mathrm{Na}_{2} \mathrm{SO}_{4}$ over the Ir-Ta 70:30, as it had a larger area, followed by Ru-Ta 30:70, IrTa 30:70 and finally Ru-Ta 70:30, taking into account the surface area of each one. This result suggests that the Ir-Ta 70:30 and Ru-Ta 30:70 surfaces could be the best options for application in the EAOP due to the high production of ${ }^{\circ} \mathrm{OH}$.

It was not possible to detect the production of hydrogen peroxide using the methodology carried out in this study. It was suggested that there was no production of $\mathrm{H}_{2} \mathrm{O}_{2}$, or at least not a significant amount to be detected in the range of 0 to $25 \mathrm{mg} \mathrm{L}^{-1}$. Therefore, the model of degradation mechanism proposed for AMX was via hydroxyl radicals, without the presence of $\mathrm{H}_{2} \mathrm{O}_{2}$ (reaction 4). Additionally, the accelerated lifetime of these surfaces was obtained in accordance with the NACE TM0108-2012 standard (Table 1). ${ }^{27}$ The surface that showed the longest accelerated lifetime was Ir-Ta 70:30, with almost $195 \mathrm{~h}$ of continuous electrolysis, showing great stability, which again makes it the best candidate for an EAOP application. The Ru-Ta 70:30 surface shows a stability of 85.6 h, followed by the Ru-Ta 30:70 surface, with $51.6 \mathrm{~h}$, and the Ir-Ta 30:70 
surface, with only $28 \mathrm{~h}$ of electrolysis. It is important to stress that the accelerated lifetime of these electrodes is not yet competitive when they are compared with traditional and commercial ones (e.g. De Nora commercial DSA ${ }^{\circledR}$ electrodes). Still, this research is an initial regarding electrophoretically modified surface electrodes and further research with the corresponding optimization will be performed before commercialization. As we reported before in the reference: ${ }^{12}$ "many researchers have studied the service accelerated lifetime of $\left|\mathrm{IO}_{2}-\mathrm{Ta}_{2} \mathrm{O}_{5}\right| \mathrm{Ti}$ anodes under galvanostatic conditions in $1 \mathrm{M} \mathrm{H}_{2} \mathrm{SO}_{4}$ over the potential region corresponding to the oxygen evolution reaction (OER). Huang, et al. (2017) ${ }^{31}$ have recently prepared compositionally similar anodes by thermal treatment, reporting a service accelerated lifetime between 70 and $110 \mathrm{~h}$. Results presented here agree with those in Comninellis et al. (1991), ${ }^{32}$ who prepared $\left|\mathrm{IO}_{2}-\mathrm{Ta}_{2} \mathrm{O}_{5}\right| \mathrm{Ti}$ electrodes by thermal decomposition at $550^{\circ} \mathrm{C}$ over a wide range of compositions from 10 to 100 mol.\% Ir. They reported maximum electroactivity, along with the greatest electrode service life, for the electrodes containing $70 \%$ Ir."

\subsection{Amoxicillin electro-oxidation using modified electrodes}

The hydrodynamic curves show that the diffusion control by mass transport in

all cases occurred at $3 \mathrm{~V}$ (Figure 3), so this potential was used to test amoxicillin $(\mathrm{AMX})$ degradation. The observed electrochemical oxidation order of AMX was Ir-Ta 70:30 > Ir-Ta 30:70 > Ru-Ta 70:30 > Ru-Ta 30:70. Therefore, the 
$\left|\mathrm{rO}_{2} / \mathrm{Ta}_{2} \mathrm{O}_{5}\right| \mathrm{Ti} 70: 30$ electrodes were demonstrated to be the best for $\mathrm{AMX}$ oxidation in aqueous medium.

Subsequently, the results of AMX degradation by electrolysis for 400 min were measured by HPLC-UV-Vis. The removal efficiency (Figure 4) was calculated using equation 8:

$$
\begin{array}{ll}
\% \text { removal }=\frac{\mathrm{Ci}-\mathrm{Cf}}{\mathrm{Ci}} \times 100 & \text { Equation } 8
\end{array}
$$

where $C_{i}$ is the initial concentration and $C_{f}$ is the final concentration. Figure $4 A$ shows the behavior of $A M X$ degradation. In the first 250 min, there was an exponential removal using the surface $\mathrm{IrO}_{2} / \mathrm{Ta}_{2} \mathrm{O}_{5} \mid \mathrm{Ti} 70: 30$, which showed the best removal efficiencies (99.23\%, Table 2$)$. This result confirms that this surface favors the electrocatalytic degradation of organic molecules, as previously reported. ${ }^{14}$ The second-best result was obtained with the $\mathrm{RuO}_{2} / \mathrm{Ta}_{2} \mathrm{O}_{5} \mid \mathrm{Ti}$ 30:70 surface $(95.14 \%$, Table 2). AMX removal percentages are consistent with the results obtained for the production of hydroxyl radicals, demonstrating that they are involved in breaking down the AMX molecule.

Figure 4B shows the results obtained for the removal efficiency in terms of the COD results. These results are consistent with the AMX removal results obtained by HPCL-UV-Vis. As shown in Table 2, the naked Ti surface showed only $53.16 \%$ of COD removal, while Ir-Ta 70:30 and Ru-Ta 30:70 surfaces showed the highest removal, with $81.13 \%$ and $78.34 \%$, respectively, although 
the AMX degradation calculated by HPLC-UV-Vis was $99.23 \%$ and $95.14 \%$. It is important to indicate that Ir-Ta and Ru-Ta surfaces have not shown leaching as reported before,${ }^{12,14}$ due to their mechanical stability.

Advanced oxidation processes, and in particular electrochemical oxidation, can play an important role in the degradation and elimination of emerging pollutants such as antibiotics from wastewaters, to curtail the spread of antimicrobial resistance (AMR), considered one of the most pressing global threats to human health in the $21^{\text {st }}$ century. However, several issues still challenge the full implementation of this treatment, such as the need to test more with real wastewaters (not just aqueous solutions and synthetic wastewaters). ${ }^{33}$ Emerging contaminants are micropollutants $\left(<1 \mu \mathrm{L} \mathrm{L}^{-1}\right)$, and it is challenging to deal with those low-level concentrations in a complex matrix like wastewater. Other issues are related to both CAPEX and OPEX of these treatments (including electrical energy for electrochemical treatment and plant operation), reactor design and optimization for scaling up, and cost of the electrodes' materials used in the electrodes.

\subsection{Energy consumption}

The energy consumption per kg of COD and efficiency of the electric current supplied to the system for each of the surfaces used as an anodic material are presented in Table 2. The Ir-Ta 70:30 surfaces displayed the highest 
consumption, with $21.29 \mathrm{Wh} \mathrm{m}^{-3}$. However, this surface showed a consumption of $39.13 \mathrm{kWh}$ per $\mathrm{kg}$ of COD removed, and the surface that showed the highest energy consumption was naked Ti with $21.16 \mathrm{Wh} \mathrm{m}^{-3}$. In addition, Ti showed the highest amount of energy consumed per $\mathrm{Kg}$ of COD, at $59.37 \mathrm{kWh}$. The Ir-Ta 30:70 surface showed a $19.31 \mathrm{Wh} \mathrm{m}^{-3}$ energy consumption, with a specific consumption of $40.39 \mathrm{~kW} \mathrm{Kg} \mathrm{COD}{ }^{-1}$. The Ru-Ta $70: 30$ surface showed the lowest power consumption, at $18.69 \mathrm{Wh} \mathrm{m}^{-3}$.

However, its specific energy consumption was $36.52 \mathrm{kWh} \mathrm{Kg} \mathrm{COD}^{-1}$, in contrast to the Ru-Ta 30:70 surfaces, which showed an energy consumption of 19.18 Whm ${ }^{-3}$, with a specific consumption of $36.52 \mathrm{KWh} \mathrm{Kg} \mathrm{COD}^{-1}$. For the current efficiency supplied (ICE), which was equivalent to the current used to decrease the COD, the order in which the results were observed was as follows: Ru-Ta 30:70 (44.04 \%) > Ir-Ta 70:30 (41.10\%) > Ir-Ta 30:70 (39.81 \%) > Ru-Ta $70: 30(38.24 \%)>\operatorname{Ti}(27.08 \%)$. These results agree with those obtained from the surfaces characterization studies, as well as the degradation of AMX in aqueous medium, showing that the $1 \mathrm{rO}_{2} / \mathrm{Ta}_{2} \mathrm{O}_{5} \mid \mathrm{Ti}$ 70:30 surface was the best for this application. This surface exhibited the highest calculated surface area (251.67 $\left.\mathrm{cm}^{2}\right)$, a working overpotential for the $\mathrm{O}_{2}$ reaction $(0.871 \mathrm{~V}$ to neutral $\mathrm{pH}$ and 0.716 $\mathrm{V}$ at acid $\mathrm{pH}$ ), a greater amount of ${ }^{\circ} \mathrm{OH}$ radicals generated per $\mathrm{cm}^{2}$ and a higher accelerated lifetime $(194.6 \mathrm{~h})$. These characteristics were used to obtain the highest AMX degradation in neutral aqueous media ( $\eta \cup v-v i s=99.23 \%$ and $\eta \operatorname{coD}$ $=81.13 \%)$ with $41.10 \%$ efficiency of the applied current (ICE). 


\subsection{Model of amoxicillin electro-oxidation}

Considering $\mathrm{AMX}$ electro-oxidation using the $\mathrm{IrO}_{2} / \mathrm{Ta}_{2} \mathrm{O}_{5} \mid \mathrm{Ti} 70: 30$ electrode, a model was conceived taking into account the six compounds established above in reactions 9 to 14 . The model showed that the concentration of $\mathrm{AMX}\left(\mathrm{C} 1, \mathrm{C}_{16} \mathrm{H}_{19} \mathrm{~N}_{3} \mathrm{O}_{5} \mathrm{~S}\right)$ decays by almost $100 \%$ as obtained experimentally, while compound $\mathrm{C}_{2}\left(\mathrm{C}_{16} \mathrm{H}_{22} \mathrm{~N}_{3} \mathrm{O}_{6} \mathrm{~S}\right)$ can be generated (Figure 5). However, most of the products would be compound $\mathrm{C} 6\left(\mathrm{C}_{16} \mathrm{H}_{22} \mathrm{~N}_{3} \mathrm{O}_{7} \mathrm{~S}\right)$, which is the main reaction product from the degradation of $\mathrm{AMX}$ by action of the ${ }^{\circ} \mathrm{OH}$ radicals generated at the interface of the Ir-Ta 70:30 surface.

Figure $5 \mathrm{~A}$ shows a comparison between experimental results (full black circles) and simulation results (continuous line) for AMX degradation using the $\left|\mathrm{rO}_{2} / \mathrm{Ta}_{2} \mathrm{O}_{5}\right| \mathrm{Ti} 70: 30$. The simulation matches the experimental data regarding the complete degradation of $\mathrm{AMX}(100 \%)$. However, the results show different kinetics, suggesting that there are different steps still unknown in the mechanism. Additionally, Figure 5B shows a comparison of the simulation (continuous line) and experimental (full black circles) results of the COD decrease using $\left|\mathrm{rO}_{2} / \mathrm{Ta}_{2} \mathrm{O}_{5}\right| \mathrm{Ti} 70: 30$. In this case, the modeling predicts and validates the COD reduction obtained experimentally considering the mechanism proposed by Trovó and collaborators ${ }^{23}$ for the electro-oxidation of $\mathrm{AMX}$ to the product $\mathrm{C} 6$ 
$\left(\mathrm{C}_{16} \mathrm{H}_{22} \mathrm{~N}_{3} \mathrm{O}_{7} \mathrm{~S}\right)$ via ${ }^{\circ} \mathrm{OH}$ generation. Further research will look in detail to identify and assess the toxicity of the AMX degradation products.

\section{CONCLUSIONS}

The morphological and elemental characterization of transition metal oxides showed that $\mathrm{IrO}_{2} / \mathrm{Ta}_{2} \mathrm{O}_{5} \mid \mathrm{Ti}$ 70:30 had the highest surface area, which was also associated with a long accelerated lifetime, showing stability for $194.6 \mathrm{~h}$ and a high production of ${ }^{\circ} \mathrm{OH}$ radicals to remove amoxicillin in aqueous medium.

The results showed that $\mathrm{IrO}_{2} / \mathrm{Ta}_{2} \mathrm{O}_{5} \mid \mathrm{Ti}$ 70:30 was the best for amoxicillin electro-oxidation, with $99.23 \%$ removal as determined by HPLC-UV-Vis and $81.13 \%$ removal by COD, after electrolysis for $6 \mathrm{~h}$ while applying $15 \mathrm{~mA}$ in $0.1 \mathrm{M}$ $\mathrm{Na}_{2} \mathrm{SO}_{4}$. Compared to the other electrodes under study, this electrode displayed a higher applied current efficiency (41.1\%), larger surface area $\left(251.67 \mathrm{~cm}^{2}\right)$, a higher amount of ${ }^{\circ} \mathrm{OH}$ radicals generated per $\mathrm{cm}^{2}\left(3.8 \mathrm{M} \mathrm{cm}^{-2}\right)$ at neutral $\mathrm{pH}$, and a longer accelerated lifetime (194.6 h) between the studied electrodes in this research.

Finally, the experimental results and simulation results for AMX degradation using $\left|\mathrm{rO}_{2} / \mathrm{Ta}_{2} \mathrm{O}_{5}\right| \mathrm{Ti} 70: 30$ electrode were compared, using the simulation of the experimental data regarding the complete degradation of AMX (100\%) determined by HPLC. Notably, the results show different kinetics, suggesting that there are different steps still unknown in the mechanism. In the case of the 
comparison of the simulation and experimental results of the COD decrease using $\left|\mathrm{rO}_{2} / \mathrm{Ta}_{2} \mathrm{O}_{5}\right| \mathrm{Ti} 70: 30$, the modeling predicts and validates the COD reduction obtained experimentally considering the mechanism proposed by Trovó and collaborators for the electro-oxidation of $\mathrm{AMX}$ to the product $\mathrm{C} 6\left(\mathrm{C}_{16} \mathrm{H}_{22} \mathrm{~N}_{3} \mathrm{O}_{7} \mathrm{~S}\right)$ via ${ }^{\circ} \mathrm{OH}$ generation. This research is an initial regarding electrophoretically modified surface electrodes and further research with their corresponding optimization will be performed before commercialization for electrochemical treatment of hospitals wastewater to eliminate emergent pollutants, such as antibiotics like AMX.

\section{ACKNOWLEDGEMENTS}

The authors thank the Mexican Council of Science and Technology (CONACyT) for financial support to develop this research. I. León thanks CONACyT for a MSc. Scholarship. H.I. Gomes acknowledges the University of Nottingham for her funding through an Anne McLaren Fellowship.

\section{FIGURE AND TABLE CAPTIONS.}

Figure 1. Electrochemical cell for amoxicillin (AMX) electro-oxidation experiments.

Figure 2. Detection of ${ }^{\bullet} \mathrm{OH}$ in $0.5 \mathrm{M} \mathrm{H}_{2} \mathrm{SO}_{4}(\mathrm{~A})$ and $0.1 \mathrm{M} \mathrm{Na}_{2} \mathrm{SO}_{4}$ (B) by UV-Vis spectra of 7-hydroxicoumarin at $277 \mathrm{~nm}$. 
Figure 3. Current-potential curves of $\mathrm{AMX}$ using $\left|\mathrm{IO}_{2} / \mathrm{Ta}_{2} \mathrm{O}_{5}\right| \mathrm{Ti}$ and $\mathrm{RuO}_{2} / \mathrm{Ta}_{2} \mathrm{O}_{5} \mid \mathrm{Ti}$ electrodes coated with an Ir-Ta or Ru-Ta ratio of 30:70 or 70:30 in $0.1 \mathrm{M} \mathrm{Na}_{2} \mathrm{SO}_{4}$.

Figure 4. Percentage removal of $A M X$ based on UV-Vis $(A)$ and $C O D(B)$ analyses by electro-oxidation at $15 \mathrm{~mA}$ applied in $0.1 \mathrm{M} \mathrm{Na}_{2} \mathrm{SO}_{4}$ using $\mathrm{Ti}$, IrO $2 / \mathrm{Ta}_{2} \mathrm{O}_{5} \mid \mathrm{Ti}$ and $\mathrm{RuO}_{2} / \mathrm{Ta}_{2} \mathrm{O}_{5} \mid \mathrm{Ti}$ electrodes coated with Ir:Ta or Ru:Ta at ratios of $30: 70$ or $70: 30$.

Figure 5. Comparison of the experimental $(\bullet)$ and simulated $(-)$ results of AMX degradation based on UV-Vis (A) and COD (B) analyses using $\left|\mathrm{rO}_{2} / \mathrm{Ta}_{2} \mathrm{O}_{5}\right| \mathrm{Ti}$ $70: 30$ in $0.1 \mathrm{M} \mathrm{Na}_{2} \mathrm{SO}_{4}$.

Table 1. Superficial and geometrical areas as well as accelerated lifetimes of the different electrodes in this study.

Table 2. Percentage removal of amoxicillin (AMX) based on HPLC - UV - Vis and COD analyses when applying $15 \mathrm{~mA}$ to the electrodes composed of Ti and modified surfaces of $\mathrm{Ti}$ in this study, as well as the specific energy consumption (EC, Wh m-3), specific energy consumption per unit of mass of COD $\left(E_{s p}, k W h\right.$ $\left.\mathrm{Kg} \mathrm{COD}^{-1}\right)$ and instant current efficiency (ICE, \%).

\section{REFERENCES}

1. Lim MW, Lau EV and Poh PE, A comprehensive guide of remediation technologies for oil contaminated soil — Present works and future directions. Mar Pollut Bull 109 (1):14-45 (2016). 
2. Silva CP, Jaria G, Otero M, Esteves VI and Calisto V, Waste-based alternative adsorbents for the remediation of pharmaceutical contaminated waters: Has a step forward already been taken? Bioresour Technol 250: 888-901 (2018).

3. Martinez JL, Environmental pollution by antibiotics and by antibiotic resistance determinants, Environ Pollut 157 (11): 2893-2902 (2009).

4. Zhu L, Santiago-Schuebel B, Xiao H, Hollert H and Kueppers S, Electrochemical oxidation of fluoroquinolone antibiotics: Mechanism, residual antibacterial activity and toxicity change. Water Res 102 (1): 52-62 (2016).

5. Brillas E and Sirés I, Electrochemical removal of pharmaceuticals from water streams: reactivity elucidation by mass spectrometry. TrAC Trends Anal Chem 70:112-121 (2015).

6. Nidheesh PV, Zhou M, Oturan MA, An overview on the removal of synthetic dyes from water by electrochemical advanced oxidation processes. Chemosphere 197:210-227 (2018).

7. Cornejo OM, Murrieta MF, Castañeda LF and Nava JL, Characterization of the reaction environment in flow reactors fitted with BDD electrodes for use in electrochemical advanced oxidation processes: a critical review. Electrochim Acta 331:135373 (2020).

8. Chen G, Electrochemical technologies in wastewater treatment. Sep Purif Technol 38(1):11-41 (2004). 
9. Mousset E, Oturan N, Van Hullebusch ED, Guibaud G, Esposito G and Oturan MA, Treatment of synthetic soil washing solutions containing phenanthrene and cyclodextrin by electro-oxidation. Influence of anode materials on toxicity removal and biodegradability enhancement. App Catal B: Environ 160161:666-675 (2014).

10. Méndez E, Pérez E, Romero O, Beltrán ED, Castro S, Corona JL, Corona A, Cuevas MC and Bustos E. Effects of electrode material on the efficiency of hydrocarbon removal by an electrokinetic remediation process. Electrochim Acta 86(30):148-156 (2012).

11. Lee J-Y, Kang D-K, Lee $\mathrm{K}$ and Chang DY, An Investigation on the electrochemical characteristics of $\mathrm{Ta}_{2} \mathrm{O}_{5}-\mathrm{IrO}_{2}$ anodes for the application of electrolysis process. Mater Sci Appl 2:237-243 (2011).

12. Herrada RA, Acosta-Santoyo G, Sépulveda-Guzmán S, Brillas E, Sirés I and Bustos $\mathrm{E}, \quad\left|\mathrm{rO}_{2}-\mathrm{Ta}_{2} \mathrm{O}_{5}\right| \mathrm{Ti}$ electrodes prepared by electrodeposition from different Ir:Ta ratios for the degradation of polycyclic aromatic hydrocarbons. Electrochim Acta 263(10):353-361 (2018).

13. Pérez-Corona M, Corona A, Beltrán ED, Cárdenas $\mathrm{J}$ and Bustos E, Evaluation of $\mathrm{IrO}_{2}-\mathrm{Ta}_{2} \mathrm{O}_{5} \mid \mathrm{Ti}$ electrodes employed during the electroremediation of hydrocarbon-contaminated soil. Sustain Environ Res 23(4):279-284 (2013).

14. Herrada R, Medel A, Manríquez F, Sirés I and Bustos E, Preparation of $\left|\mathrm{rO}_{2}-\mathrm{Ta}_{2} \mathrm{O}_{5}\right| \mathrm{Ti}$ electrodes by immersion, painting and electrophoretic deposition 
for the electrochemical removal of hydrocarbons from water. J Hazard Mater 319:102-110 (2016).

15. Krstić $\vee$ and Pešovski $B$, Reviews the research on some dimensionally stable anodes (DSA) based on titanium. Hydrometallurgy 185:71-75 (2019).

16. Rossmeisl J, Qu ZW, Zhu H, Kroes GJ and Nørskov JK, Electrolysis of water on oxide surfaces. J Electroanal Chem 607(1-2):83-89 (2007).

17. Sone $\mathrm{Y}$, Kishimoto A and Kudo $\mathrm{T}$, Proton conductivity of spin-coated $\mathrm{Ta}_{2} \mathrm{O}_{5}$ - $\mathrm{nH}_{2} \mathrm{O}$ amorphous thin films from peroxo-polytantalate solution. Solid State Ionics 66(1-2):53-59 (1993).

18. Mehdipour M, Tabaian $\mathrm{SH}$ and Firoozi S, Effect of $\mathrm{IOO}_{2}$ crystallinity on electrocatalytic behavior of $\mathrm{IrO}_{2}-\mathrm{Ta}_{2} \mathrm{O}_{5} / \mathrm{MWCNT}$ composite as anodes in chloralkali membrane cell. Ceram Int 45(16):19971 (2019).

19. Ensano BMB, Borea L, Naddeo $\mathrm{V}$, Belgiorno $\mathrm{V}$, de Luna MDG, Balakrishnan $\mathrm{M}$ and Ballesteros FC, Applicability of the electrocoagulation process in treating real municipal wastewater containing pharmaceutical active compounds. J Hazard Mater 361:367-373 (2019).

20. Moreira FC, Boaventura RAR, Brillas E and Vilar VJ, Electrochemical advanced oxidation processes: a review on their application to synthetic and real wastewaters. Appl Catal B: Environ 202:217-261 (2017).

21. Sopaj F, Rodrigo MA, Oturan N, Podvorica FI, Pinson J and Oturan MA, Influence of the anode materials on the electrochemical oxidation efficiency. 
Application to oxidative degradation of the pharmaceutical amoxicillin. Chem Engin J 262(15):286-294 (2015).

22. Shi X, Yeap TSh, Huang S, Chen J and Ng HY, Pretreatment of saline antibiotic wastewater using marine microalga. Bioresour Technol 258:240-246 (2018).

23. Trovó AG, Nogueira RFP, Agüera A, Fernandez - Alba AR and Malato S, Degradation of the antibiotic amoxicillin by photo - Fenton process - Chemical and toxicological assessment. Water Res 45:1394-1402 (2011).

24. Santos D, Pacheco MJ, Gomes A, Lopes A and Ciríaco L, Preparation of $\mathrm{Ti} / \mathrm{Pt} / \mathrm{SnO}_{2}-\mathrm{Sb}_{2} \mathrm{O}_{4}$ electrodes for anodic oxidation of pharmaceutical drugs. J Appl Electrochem 43:407-416 (2013).

25. Panizza $M$, Dirany $A$, Sirés I, Haidar $M$, Oturan $N$ and Oturan MA, Complete mineralization of antibiotic amoxicillin by electro-Fenton with a BDD anode. J Appl Electrochem 44:1327-1335 (2015).

26. Zhandong R, Shanshan Q, Jie G, Wenyang L, Yuchan Z, Ye L, Bo C and Yourong $\mathrm{W}$, The electrocatalytic activity of $\mathrm{IrO}_{2}-\mathrm{Ta}_{2} \mathrm{O}_{5}$ anode materials and electrolyzed oxidizing water preparation and sterilization effect. Royal Soc Chem 5:8778-8786 (2015)

27. Company H, Manual de análisis de agua, 2 ed., Loveland, Colorado, EE.UU. (2000). 
28. Martínez - Huitle CA, Rodrigo MA, Sirés I and Scialdone O, Single and coupled electrochemical processes and reactors for the abatement of organic water pollutants: a critical review. Chem Rev 115:13362-13407 (2015).

29. Zavala Salazar NJAS, Modelo cinético para el proceso de desintegración catalítica considerando la descomposición de la carga alimentaria. México D.F.: Instituto Politecnico Nacional (2011).

30. Huang CA, Yang SW, Chen CZ and Hsu F-Y, Electrochemical behavior of $\mathrm{IrO}_{2}-\mathrm{Ta}_{2} \mathrm{O}_{5} \mid \mathrm{Ti}$ anodes prepared with different surface pretreatments of $\mathrm{Ti}$ substrate. Surf Coating Technol 320:270-278 (2017).

31. Comninellis $C$ and Vercesi GP, Characterization of DSA ${ }^{\circledR}$ - type oxygen evolving electrodes: choice of a coating. J Appl Electrochem 21:335-345 (1991). 32. Moreira FC, Boaventura RAR, Brillas E and Vilar FJP, Electrochemical advanced oxidation processes: a review on their application to synthetic and real wastewaters. App Catal B: Environ 202:217-261 (2017). 
Table 1.

\begin{tabular}{ccccc}
\hline Electrode & $\mathbf{A}_{\text {real }}\left(\mathbf{c m}^{2}\right)$ & $\mathbf{A}_{\text {geo }}\left(\mathbf{c m}^{2}\right)$ & $\mathbf{R}$ & $\begin{array}{c}\text { Acelerated } \\
\text { Lifetime (h) }\end{array}$ \\
\hline Ti & 95.00 & & 7.00 & - \\
\hline Ir-Ta 30:70 & 126.67 & 9.3 & 28.0 \\
\hline Ir-Ta 70:30 & 251.67 & & 18.5 & 194.6 \\
\hline Ru-Ta 30:70 & 128.67 & 13.58 & 9.5 & 51.6 \\
\hline Ru-Ta 70:30 & 153.33 & & 11.3 & 85.6 \\
\hline
\end{tabular}


Table 2.

\begin{tabular}{|c|c|c|c|c|c|}
\hline \multirow{2}{*}{ Surface } & \multicolumn{2}{|c|}{$\%$ removal } & \multirow{2}{*}{$\begin{array}{c}\text { EC } \\
\left(\mathrm{Wh} \mathrm{m}^{-3}\right)\end{array}$} & \multirow{2}{*}{$\begin{array}{c}\mathrm{E}_{\mathrm{sp}} \\
\left(\mathrm{kWh} \mathrm{Kg} \mathrm{DQO^{-1 }}\right)\end{array}$} & \multirow{2}{*}{$\begin{array}{l}\text { ICE } \\
(\%)\end{array}$} \\
\hline & HPLC - UV - Vis & COD & & & \\
\hline $\mathrm{IrO}_{2} / \mathrm{Ta}_{2} \mathrm{O}_{5} \mid \mathrm{Ti} 30: 70$ & 87.31 & 71.29 & 19.31 & 40.39 & 39.81 \\
\hline $\mathrm{O}_{2} / \mathrm{Ta}_{2} \mathrm{O}_{5} \mid \mathrm{Ti} 70: 30$ & 99.23 & 81.13 & 21.29 & 39.13 & 41.10 \\
\hline $\mathrm{KuO}_{2} / \mathrm{Ta}_{2} \mathrm{O}_{5} \mid \mathrm{Ti} 30: 70$ & 95.14 & 78.34 & 19.18 & 36.52 & 44.04 \\
\hline $\mathrm{uO}_{2} / \mathrm{Ta}_{2} \mathrm{O}_{5} \mid \mathrm{Ti} 70: 30$ & 92.08 & 66.28 & 18.69 & 42.05 & 38.24 \\
\hline 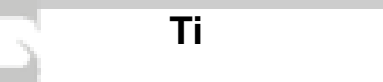 & 76.50 & 53.16 & 21.16 & 59.37 & 27.08 \\
\hline
\end{tabular}


Figure 1.

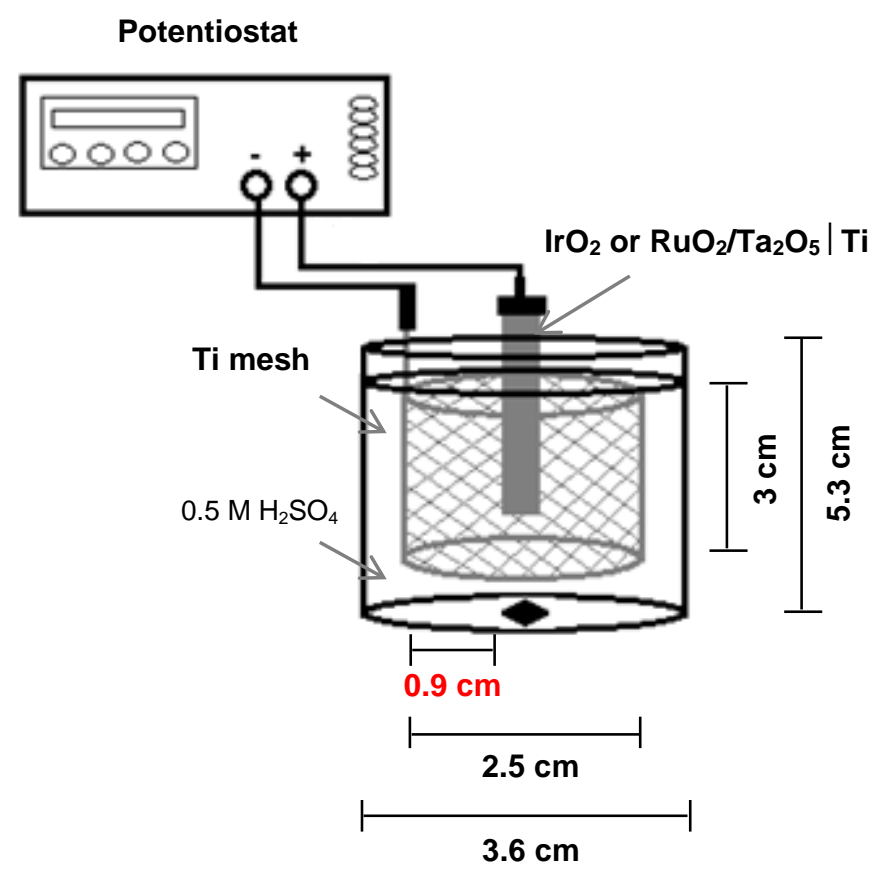

This article is protected by copyright. All rights reserved. 
Figure 2.

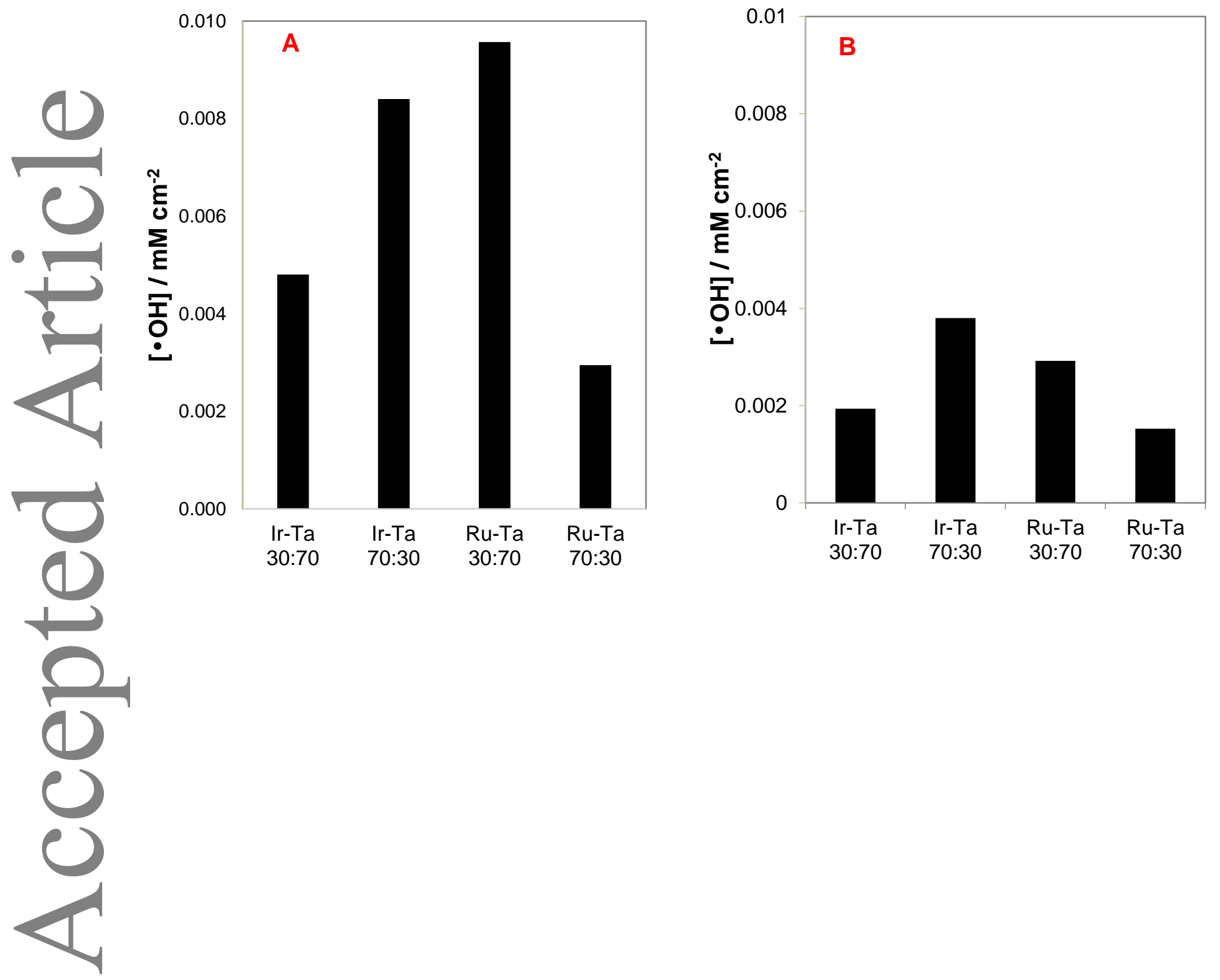


Figure 3.

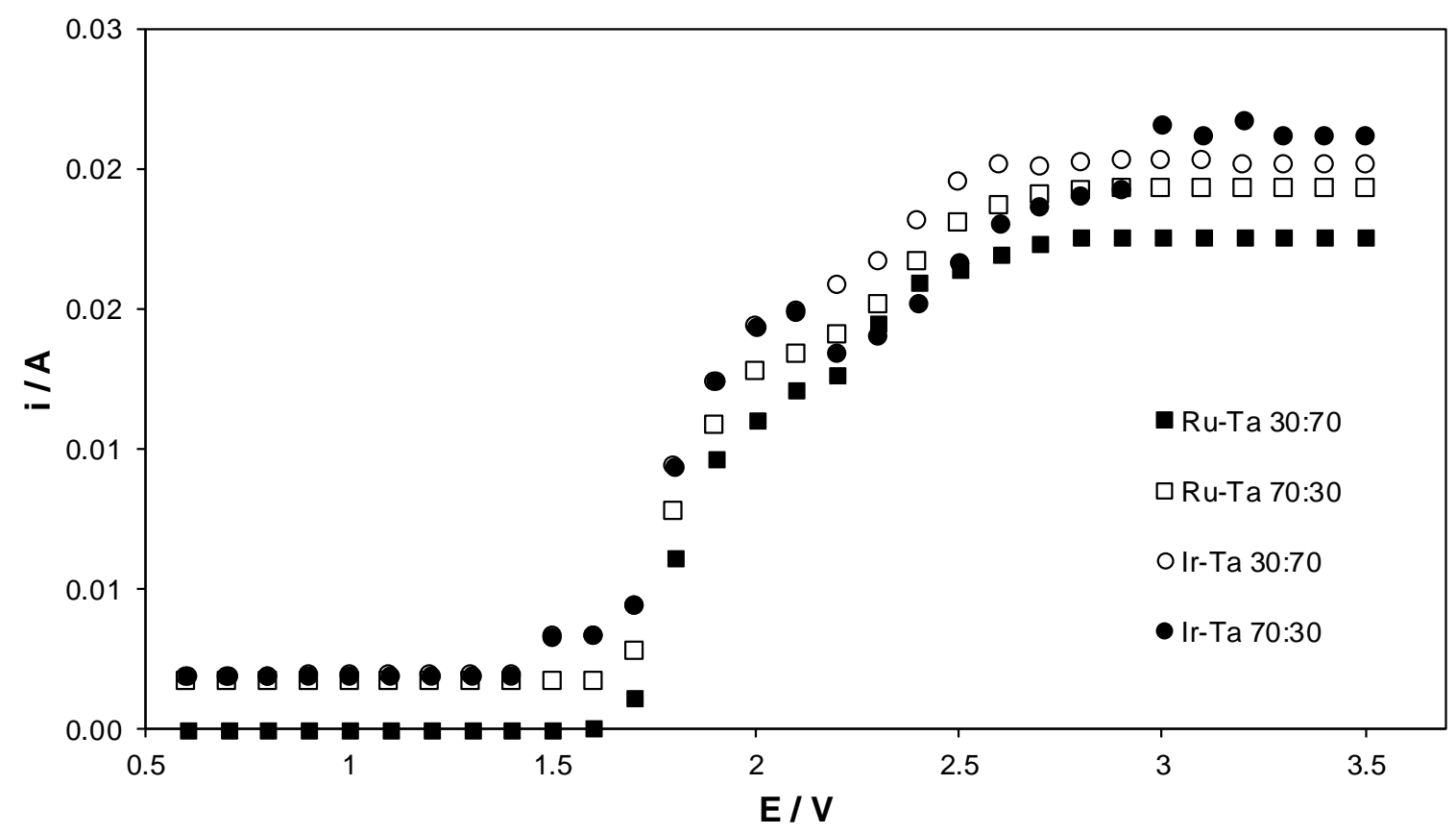


Figure 4.
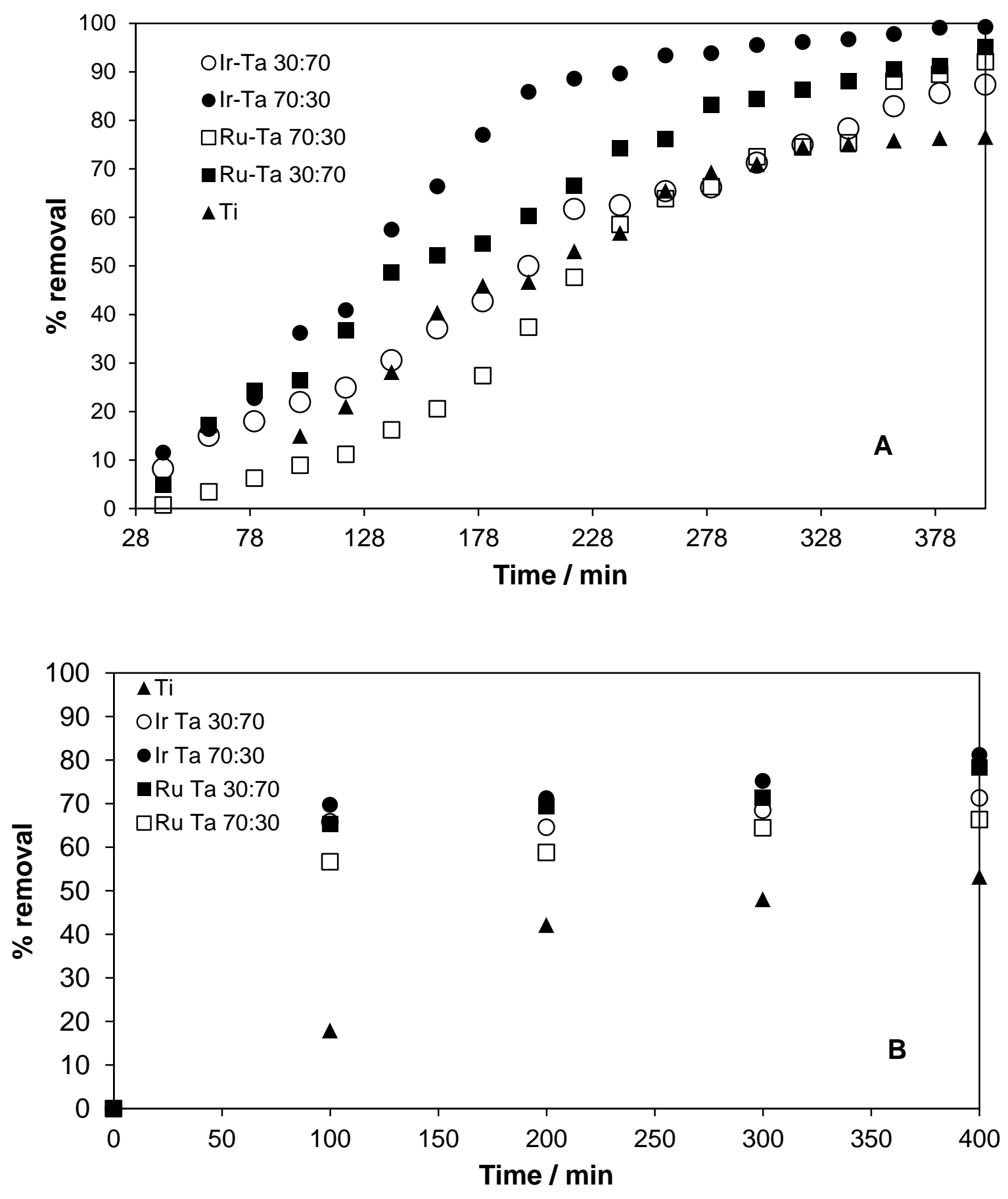
